long-range cruise (non-ballistic) missile (LRCM). It can be launched either from submarines or from aircraft, and has both tactical and strategic capabilities. Its distinctive feature is great accurary of delivery: an accuracy which $\rightarrow$ also being built into the class of conventional weapons known as precision guided munitions. Such munitions now include a whole range of air-to-air, surface-to-air, air-to-surface and surface-to-surface weapons. The conventional battlefield is taking on a new look with the development of automated aids such as night vision equipment, artificial sensors which locate targets, command and control, and information-processing systems, all of which are bringing the automated battlefield nearer and nearer.

Against this background of threatening proliferation, increasing militarisation and new weapons technologies, the Yearbook cannot point to any convincing measures of arms control or disarmament. The meeting between
President Ford and General Secretary Brezhnev in Vladivostok in November 1974 set the limit of missiles with multiple independently-targeted reentry warheads at 1,320: more than either side had deployed at the time of the accord. Presumably such a high figure was chosen so that each side could complete its planned deployments and still reap the political benefits of having arrived at an agreement. A similar situation obtained in the Threshold Test Ban Treaty, signed in July 1974 by the USA and the USSR. Each side undertook not to carry out any tests having a yield of more than 150 kilotons. Again, this limit is so high that it does not interfere with any tests intended by either side for any tactical and most strategic nuclear weapons at present deployed or even planned. The cynicism of the agreement is even more glaring given that refinements in accuracy are presently being pursued more enthusiastically than refinements in size. In fact, 1974 was a record year for the number of nuclear explosions touched off by all countries. In all, 35 explosions were carried out: 20 by the USSR, 5 by the USA, 7 by France and 1 by each of the UK, China and India. Treaties such as the Threshold Ban do nothing to limit the number of tests carried out by the signatory states, or to slow down the arms race.

SIPRI has a way of making the facts seem compelling. And yet there is more to international relations than just facts. The Yearbooks are invaluable for their collation and analysis of facts, but they do not analyse to what extent these facts influence the behaviour of decision makers. To enter this realm would admittedly be to go beyond the task SIPRI has set itself; and yet without it the Yearbook's pessimism occasionally seems too relentless. What is indisputable, however, is that the facts add up to more armament and no disarmament. And there is no change in sight.

\title{
correspondence
}

\section{In defence of MIT}

Sir,-I am not often shocked by Nature, so all the greater the impact when that happens. It has just happened as the result of reading your leading article in the issue of May 22.

It is not one of your best, witness such an impenetrable sentence as: "And one thing that ought to have been learnit is that the isolation of scientific and other intellectual pursuits, particularly from bodies which claim to be representative, profits noone and is a futile gesture in the face of strong regimes."

But this anticle ends with a clear and to me utterly reprehensible paragraph, saying that not all divisiveness stems fnom developing nations: "it should be added that some of the initiatives of the developed world seem only capable of generating bad feelings"; and then citing as its single example of such deplorable provocations that the Massachusetts Institute of Technology made acts of religious discrimination a cause for terminating a projected contract involving water desalination with Saudi Arabia. The Nature editorial ends: "Saudi Arabia can hardly welcome Jews with open arms; it surely behoves MIT to use restraint and not to trigger confrontation by insisting on sending them."

The relevant stipulations were in fact not written into the projected contract, but appeared in a covering letter from Jerome Wiesner, President of MIT. This stated in effect that under speciral circumstances either party could withdraw from the arrangement, and that MIT would feel abliged to terminate the contract if systematic discrimination in employment under the contract were exercised on the basis of race, colour, national origin, religion or sex. Such considerations govern all MIT employment, and are now required by American law. Saudi Arabia responded by withdrawing the proposal.

I am proud of MIT, which needed no prodding from the US government to adopt such practices since they are backed strongly by its faculty and students; and I am proud of the US government for having such laws.

But what are we to make of Nature?

$$
\begin{aligned}
& \text { Yours faithfully, } \\
& \text { GEORGE WALD }
\end{aligned}
$$

Harvard University

\section{Fossil footprints}

Sir,- - The account of the finding of a fossilised human footprint in Turkey (Nature, April 17) would seem to indicate that fossil human footprints are now becoming scientifically respectable.

If this is so, readers might be interested in comparing those found in and around the Paluxy River, near Glen Rose, Texas, in rock usually identified as Cretaceous. The unusual thing there is that dinosaur footprints are found in the same strata.

These footprints have been shown in a well known film Footprints in Stone. Also, descriptions and comments have been given from time to time in the Creation Research Society Quarterly.

I have seen neither the prints themselves from Texas nor, of course, those from Turkey. On the basis of photographs, however, I can only say that the prints from Texas appear to be much better ones.

Kingston, Ontario

$$
\text { H. L. Armstrong }
$$

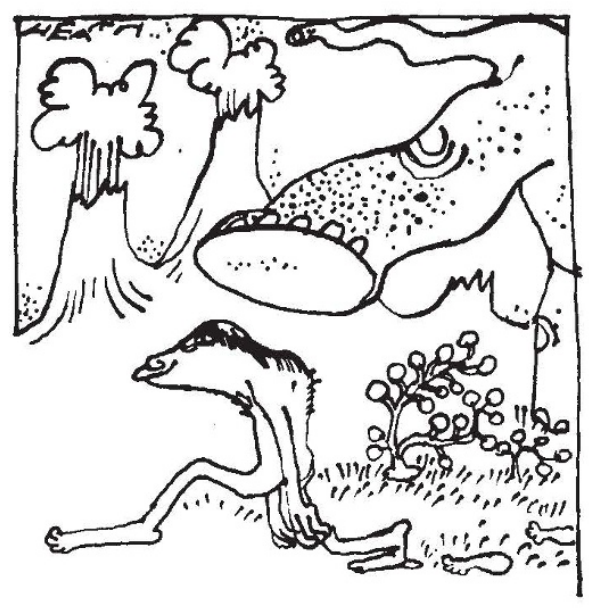

